\title{
Obstacles of the Partnership between Governmental and Civil Organizations Face When Tackling Illegal Migration in Egypt
}

Nour Al Hoda A. Afifi (Ph.D.) Amira M. Fayed (Ph.D.)

Community Organization Department Higher Institute of Social Work in Cairo 
Egyptian Journal of Social Work (EJSW)

http://ejsw.journals.ekb.eg

Print ISSN: 2356-9204 Online ISSN: 2356-9212 Vol 7, Issue 1, January 2019 


\section{Abstract:}

This study is an analytical descriptive study to identify obstacles the partnership between governmental and civil organizations face in tackling illegal migration in Egypt.

The study used the social survey methodology for a group of governmental officials and non-governmental officials responsible for illegal migration reached a sample of (45). The study used a questionnaire tool to determine the obstacles faced by governmental and civil organizations. The results of the study identified the existence of obstacles associated with the policies of tackling illegal migration, as well as weak legal protection programs for the victims of illegal migration, and the lack -of real roles for civil institutions in the development of special laws to confront illegal migration.

\section{Key words:}

Obstacles - partnership - governmental organization - nongovernmental organization - illegal migration.

\section{Introduction:}

Human movements have been a phenomenon throughout history. The world has witnessed many human migrations during the centuries. However, the twentieth century is the century of human migration, especially the last few decades, which have seen huge migration from south to north; mainly from Africa, the Middle East and the subcontinent to Europe and the Americas (UNESCO, 2003, p. 26).

Since the 1980s, there have been an increasing number of incentives for international migrations, with further incentives expected in the future. In many countries, population growth exceeds the pace of employment creation. Internal disturbances caused by political, ethnic and religious frictions reduce many to refugee status, who take shelter in safer and more prosperous countries (Yoshida, 2000). The reasons for illegal migration are economic, political, and social in nature and thus similar to those for legal migrations. The most common types of illegal migration are the following:

1) Entering a country illegally without immigration inspection.

2) Entering a country seemingly legally with fraudulent identity document.

3) Entering a country legally on a visa but then violating visa conditions. (Jenny, 2012, p.p. 1164 -1166).

In order to tackle the problem of illegal migration in Egypt, there must be an integrated system of government efforts in all areas 
(security, economic and political). But these are not enough, so the concept of partnership has -emerged. Although the active role and emphasis is on the importance of partnership, there are many obstacles that limit the effectiveness of partnership and its ability to achieve goals. This is what we will show in this study.

\section{Study problem:}

Young people are the foundation of the progress of nations, where they make up the majority of the labor market. A development worker is characterized by the physical, psychological and mental abilities and characteristics that enable him to assume development responsibilities and the progress of nations. Youths face a lot of problems in society, especially economic ones, the most of which is poverty and substandard living along with unemployment of all kinds. The problem of illegal migration has emerged as a solution to this problem, where it has become the hope for future wealth.

Illegal immigration has received great attention at the national, regional and international level because of its serious political, economic and security implications, especially with the growing phenomenon of international terrorism after the revolutions of the Arab Spring. Despite this concern and efforts, the problem is still ongoing and growing. International statistics estimate that the number of young Egyptians who succeeded in entering the EU over the last ten years are 460.000 young people, including 90.000 residing in Italy illegally and some 8000 young people from Egyptian villages residing in Italy. (Report of the Egyptian Rights Organization, 2007, pp. 4-5)

Illegal emigration is one of the most significant problems to strike the Egyptian region. Therefore, governmental and nongovernmental efforts should be combined to confront this problem and limit its spread namely though improved security and awareness programs. The seriousness of the problem requires multiple preventive and curative interventions, and specialists working in the field so that prevention and treatment are more effective. (Ebrahim, 2008, p. 18).

Several studies have been conducted on the issue of illegal immigration, in terms of description, analysis, identification of causes or plans for confrontation and treatment. The study of Salah (2005) looks at the dimensions of cultural and social factors for Egyptians migrating from the countryside to Italy. It describes the economic reasons for illegal immigration in which the major factor is unemployment, and social reasons, such as the tradition of relatives to provide for the cost of marriage. In the study by Tahar (2012) that was conducted on planning, found indicators that reduce the illegal 
migration of young Egyptians. The study aimed at determining the aspirations of young people towards migration and the civil efforts to reduce illegal migration.

Illegal immigration has a negative effect on an immigrant's well- being who no longer feels like a citizen in his homeland.

Government agencies in any country have a significant role and responsibility in confronting illegal migration. The study by (Abdel-Sattar,2014) shows the role of government agencies in confronting the phenomenon of illegal immigration in Egyptian society. The official numbers of young people who were prevented from migration were presented and proposals were made to tackle the phenomenon.

In Egypt, a comprehensive study was conducted on the illegal migration of Egyptian youth, that was commissioned by the National Center for Social and Criminal Research,..The National Coordinating Committee for combating and preventing illegal immigration conducted a field study to inform all factors leading to the increasing phenomenon. The development of an integrated strategy, in which government and non-government efforts were made to protect and confront this negative phenomenon that faces Egyptian Society. (National Center for Social and Criminal Research, 2016) Thus, it is clear that the international and national interest in the problem of immigration, has led to the attention of all organizations both governmental and private, in the case of illegal migration.

Several studies have been conducted on the role of NGOs in contributing to the problem of illegal migration. Sayad's (2011) study dealt with the efforts of private associations in providing education to improve knowledge of illegal immigration and try to reach a future vision of organizing society to do carry out the role of private associations in achieving community awareness of the dangers of illegal migration. Thus, it is clear the active role that civil society organizations play in helping tackle the problem of illegal immigration amongst, both young people and their families.

The Human development report for Egypt in 2014 affirmed that civil society organizations are the most effective tool in achieving the developmental goals of the new millennium.

Several studies have been conducted, which demonstrate the need for concerned partnerships between the government and civil society organizations.. (Human Development Report, 2014, p.155). The study by Sun,Oiu (2008) showed the partnership between the government and NGOs in the UK, and that the British government 
continuously strengthens its cooperation with non-governmental organizations to improve and satisfy public needs. In a study by Hassan (2014) on the partnership between governmental organizations and civil society organizations in contributing to the development of slums, a description of the partnership between government and nongovernment organizations was presented. Another study by Ataya (2016) explains the role of partnership in supporting universities, abilities to serve society from the perspective of organizing society, and show the importance of the role that can be played by partnership in the community in order to achieve their goals and improve the quality of life.

It is clear from previous studies the vital role that civil society organizations play in cooperation with governmental organizations tackle the problem of illegal immigration, which called on Egypt to establish a national coordinating committee to combat and prevent illegal migration (NCCPIM), Despite the efforts of the committee, the problem of illegal immigration still exists. The studies confirm the existence of obstacles that limit the partnership between governmental organizations and civil society organizations in facing the problem. Based on the above, the study problem was identified as the following (Identify the obstacles facing partnerships between governmental and non-governmental organizations tackling illegal immigration in Egypt).

\section{Theoretical Guide lines of the research:}

\section{The theory of organizations:}

Organizations are groups of people pursuing their interest by being formally committed to a common purpose, mutual relations at work and to agreed methods of work. Organizations function in a physical world and need resources in the appropriate form of energy, such as human physical and intellectual energy, as well as non-human sources of energy. (Heder\&Hedidi, 1995). 


\section{Networking Strategy:}

We aim to create useful working relationships with members, organizations and appropriate bodies, and acquire skills through positive networking between these organizations.

\section{Research goals:}

(1) Identify the obstacles facing partnerships between government and non-government organization that tackle illegal migration in Egypt.

(2) Identify the differences between governmental and nongovernmental organizations regarding the obstacles of facing partnerships tackling illegal migrations in Egypt.

(3) Propose a future vision from the perspective of the way in which the community is organized, to increase partnerships between governmental and non-governmental organizations tackling illegal migration in Egypt.

\section{Method Hypotheses:}

(1) The first hypothesis of the study: "It is expected that the level of obstacles facing partnerships between governmental and nongovernmental organizations to tackling illegal migration in Egypt is numerous.. This hypothesis can be tested through the following indicators:

1- Constraints related to policies, which address illegal migration.

2- Constraints related to laws and legislations.

3-Constraints associated with governmental and nongovernmental organizations.

4- Constrains related to lct. (Clarify)

5-Constraints related to the staff of governmental and nongovernmental organizations.

(2) The second hypothesis of the study: "There are statistically significant differences between the governmental and nongovernmental organizations to tackling illegal migration.

\section{The concepts:}

\section{Illegal immigration is defined as:}

Travel across borders in a manner contrary to the laws and legislation in force in the country and illegal immigrants many methods to reach those countries, which puts them at risk of many dangers as in the case of migrants to the countries of the European Union. (Saadi, 2006, P. 124) 


\section{Partnership is defined as:}

The concept of partnership refers to the cooperation and interdependence of two or more parties to achieve common goals with a positive return on the parties to this relationship. (Abo Elnassar, 2007, p. 77)

The operational definition of partnership under this study is: Cooperation between governmental and non-governmental organizations that work together to address illegal migration and to achieve integration.

\section{Governmental organization is defined as:}

The organizational entity of the executive authority and leading position such as the head of state, ministers and their assistants. (Sharief, 2005, p. 21)

\section{Non-governmental organizations (NGOs) are defined as:}

The World Bank defines NGOs as an informal network of governmental organizations, international aid institutions and nongovernmental organizations aimed at clarifying the proper ways dynamically stimulate partnerships to provide additional benefits to both communities and partners. (Business partners for Developments, 2000, P. 1)

\section{Operational definition of obstacles of partnership:}

Obstacles associated each of the policies of confronting illegal migration, laws and legislation in confrontation illegal migration, the nature of the work of governmental organizations and civil society. and information technology between governmental organization and civil society to face illegal migration. These obstical were measured by questionnaire designed by authors

\section{Methodology:}

This study belongs to the pattern of descriptive studies, and aims to identify the obstacles faced by partnerships between governmental and civil organizations tackling the problem of illegal migration. This study used the social survey methodology for a group of responsible officials as a sample.

\section{Tools:}

The study designed a questionnaire for the officials by reference to the theoretical heritage and related studies, in addition to taking advantage of some of the standards and questionnaire forms related to the subject of the study. 


\section{Design of the study questionnaire:}

Questionnaire for officials about obstacles of partnership between government and civil efforts illegal migration in Egypt:

The researchers designed a questionnaire for the officials by reference to the theoretical heritage and related studies, in addition to taking advantage of some of the standards and questionnaires derived from related to_studies. The reliability of the tool was presented after the presentation of five faculty members at the faculty of social work, Helwan University and the Higher Institute of Social Work in Cairo. The agreement was not less than 80 percent. Accordingly, the form was finalized. The statistical stability of a sample of (10) members of officials using the coefficient of alpha - Kronbach, indicated a stability factor of .84 , which is suitable for statistical stability.

\section{Sample:}

1- The study was conducted in Cairo where governmental organizations responsible for illegal migration are based and was conducted by the Office of Egyptians Aboard and the Ministry of Immigration and the Ministry of Power Working that assists Egyptian youth. A total number of 15 officials were involved in the study.

2- The purposive sample of the Egyptian Human Rights organizations reached 30 officials. The study took place in April and May 2015.

3- This Limited Figure was obtained due to the difficulties of obtaining a particular sample on the governmental side.

\section{Reasons for choosing the study community:}

1- The study took place within Cairo due to the Ministry of Power Working for Egyptian Youth was based in that city.

2- The office of the Care of Egyptians Abroad in the Ministry of Immigration is responsible for immigration in Egypt.

3- The Egyptian Human Rights Organization is one of the civil organizations in Cairo that take care of illegal immigration. 
Egyptian Journal of Social Work (EJSW)

http://ejsw.journals.ekb.eg

Print ISSN: 2356-9204 Online ISSN: 2356-9212

Vol 7, Issue 1, January 2019

\section{Description of Officials of the Study community:}

Table (1) Description of officials of the study community

$(\mathrm{N}=45)$

\begin{tabular}{|c|c|c|c|}
\hline $\mathrm{N}$ & Quantitative variables & Mean & Std. D \\
\hline 1 & Age & 31 & 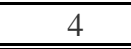 \\
\hline 2 & Years of work experience & 6 & 2 \\
\hline $\mathrm{N}$ & Gender & Frequency & Percent \\
\hline 1 & Male & 27 & 60 \\
\hline 2 & Female & 18 & 40 \\
\hline \multicolumn{2}{|r|}{ Total } & 45 & 100 \\
\hline $\mathrm{N}$ & Qualification & Frequency & Percent \\
\hline 1 & Bachelor's Degree & 29 & 64.4 \\
\hline 2 & Postgraduate & 16 & 35.6 \\
\hline \multicolumn{2}{|r|}{ Total } & 45 & 100 \\
\hline $\mathrm{N}$ & Career & Frequency & Percent \\
\hline 1 & Lawyer & 19 & 42.2 \\
\hline 2 & Researcher & 9 & 20 \\
\hline 3 & International Relations Officer & 3 & 6.7 \\
\hline 4 & OFfficial of the Egyptians Abroad Office & 6 & 13.3 \\
\hline $\mathrm{N}$ & Career & Frequency & Percent \\
\hline 5 & An official in the Ministry of Manpower & 3 & 6.7 \\
\hline 6 & $\begin{array}{l}\text { Member of the Board of Directors of the } \\
\text { organization. }\end{array}$ & 5 & 11.1 \\
\hline \multicolumn{2}{|r|}{$\begin{array}{c}\text { Total } \\
\end{array}$} & 45 & 100 \\
\hline $\mathrm{N}$ & Dependence of organizations & Frequency & Percent \\
\hline 1 & Governmental organizations & 15 & 666.7 \\
\hline 2 & Civil Organizations (NGOs) & 30 & 33.3 \\
\hline \multicolumn{2}{|r|}{ Total } & 45 & 100 \\
\hline
\end{tabular}

\section{The Table Above Shows That:}

- Mean age of officials is 31 years old, with a standard deviation of four years.

- Mean number of years of experience in the field of work is six years, and with a standard deviation of approximately two years.

- The largest percentage were male officials $(60 \%)$, while females were $(40 \%)$.

- The highest proportions of officials have a university qualification $(64.4 \%)$, and then higher studies (35.6\%).

- The largest percentage of officials are lawyers (42.2\%), researchers (20\%), Officials of the Egyptians Abroad Office (\%13.3), Members of the Board of Directors of the organizations $(11.1 \%)$, and finally International Relations Officer, who is an official in the Ministry of Manpower (6.7\%).

Methods of statistical analysis: 
Data were processed through the computer using the program (SPSS.V. 17.0) a statistical packages for social sciences, and the following statistical methods were applied:

1. Duplicates and percentages: to describe the characteristics of the study community.

2. The Arithmetic Mean: To judge the level of obstacles facing partnerships between governmental and civil organizations tackling illegal migration in Egypt, so that the beginning and end of the triple scale categories are: yes (three degrees), to some degree (two degrees), no (one degree) $(3-1=2)$, divided by the number of cells of the scale to obtain the length of the corrected cell $(2 / 3=0.67)$. This value was then added to the lowest value in the scale or beginning of the scale, the correct one, to determine the maximum limit for this formula.

Table (2) Levels of arithmetic mean

\begin{tabular}{||c||c||}
\hline \hline If the mean value of a phrase or dimension varies from 1 to less than 1.67 & Low level \\
\hline \hline If the mean value of a phrase or dimension ranges from 1.67 to less than 2.35 & Medium level \\
\hline \hline If the mean value of the phrase or dimension varies from 2.35 to 3 & High level \\
\hline
\end{tabular}

3. Standard deviation: It is useful to know the extent of dispersion or non-dispersion of respondents' answers. It also helps to rank the terms with the arithmetic mean. If the terms are equal in the arithmetic mean, the less standard deviation takes the higher order.

4. Range: It is calculated by the difference between the largest value and the lowest value.

5. Stability coefficient (Alpha Kronbach): Values of the stability of the estimated tools of the study.

6. Independent Samples $T$ - Test: To identify the differences and their statistical significance, in the variables that are divided into two groups only (test of study hypotheses).: 


\section{Results:}

Frist: The obstacles faced by partnerships between governmental and civil organizations tackling illegal migration in Egypt:

(1) Obstacles Related to Polices Confronting Illégal Migration :

Table (3) obstacles related to the policies that confront illegal migration as determined by the officials

\begin{tabular}{|c|c|c|c|c|}
\hline $\mathrm{N}$ & The Phrases & Mean & $\begin{array}{c}\text { Std. } \\
\text { D }\end{array}$ & Rank \\
\hline 1 & Absence of research policy on illegal migration issues & 2.76 & 0.43 & 2 \\
\hline 2 & $\begin{array}{l}\text { Non-participation of governmental and non- } \\
\text { governmental organizations in the formulation of the } \\
\text { national plan of action to address illegal migration }\end{array}$ & 2.82 & 0.39 & 1 \\
\hline 3 & $\begin{array}{l}\text { There is difference in vision, mission and philosophy } \\
\text { among partners to confront illegal migration }\end{array}$ & 2.53 & 0.66 & 4 \\
\hline 4 & $\begin{array}{l}\text { Poor public awareness of the importance of } \\
\text { partnership between governmental and } \\
\text { nongovernmental organizations to confront illegal }\end{array}$ & 2.58 & 0.54 & 3 \\
\hline 5 & $\begin{array}{l}\text { Lack of a viable strategy in the field of combating } \\
\text { illegal migration }\end{array}$ & 2.33 & 0.64 & 5 \\
\hline & Total & 2.6 & 0.35 & $\begin{array}{l}\text { High } \\
\text { level }\end{array}$ \\
\hline
\end{tabular}

\section{The Table Above Shows That:}

The level of the obstacles related to the policies that confront illegal migration as determined by the officials, is high with an arithmetic mean of 2.6 and indicators according to the order of the arithmetic mean that ranked first was non-participation of governmental and non-governmental organizations in the formulation of the national plan of action to address illegal migration with an arithmetic mean of 2.82. Ranked second was the absence of research policy on illegal migration issues with an arithmetic mean of 2.76 and finally, the lack of a viable strategy in the field of combating illegal migration with an arithmetic mean of 2.33 . 
(2) Obstacles Related to Laws and Legislation:

Table (4) obstacles related to Laws and Legislation as determined by the officials.

\begin{tabular}{||c||l||c||c||c||}
\hline $\mathrm{N}$ & \multicolumn{1}{|c||}{ The Phrases } & Mean & $\begin{array}{c}\text { Std. } \\
\mathrm{D}\end{array}$ & Rank \\
\hline \hline 1 & $\begin{array}{l}\text { Absence of the legal culture associated with the } \\
\text { partnership between governmental and non- } \\
\text { governmental organizations to confront illegal } \\
\text { migration. }\end{array}$ & 2.58 & 0.66 & 1 \\
\hline \hline 2 & $\begin{array}{l}\text { Problems related to the regulations and laws associated } \\
\text { with governmental and non-governmental } \\
\text { organizations. }\end{array}$ & 2.58 & 0.66 & 1 \\
\hline \hline 3 & $\begin{array}{l}\text { The rigidity of some laws and legislations related to } \\
\text { illegal migration. }\end{array}$ & 2.4 & 0.72 & 3 \\
\hline \hline 4 & $\begin{array}{l}\text { Failure to formulate national legislation to counter } \\
\text { illegal migration. }\end{array}$ & 2.51 & 0.63 & 2 \\
\hline \hline 5 & $\begin{array}{l}\text { Weak legal protection programs for victims of illegal } \\
\text { migration. }\end{array}$ & 2.36 & 0.71 & 4 \\
\hline \hline \multicolumn{2}{|c||}{ Total } & 2.48 & 0.48 & $\begin{array}{l}\text { High } \\
\text { level }\end{array}$ \\
\hline
\end{tabular}

\section{The Table Above Shows That:}

The level of obstacles related to Laws and Legislation as determined by the officials is high, with an arithmetic mean of 2.48. Indicators according to the order of the arithmetic mean identify the top ranked factor was the absence of the legal culture associated with the partnership between governmental and non-governmental organizations to confront illegal migration, and problems related to the regulations and laws associated with governmental and nongovernmental organizations, with an arithmetic mean of 2.58. Ranked second was the failure to formulate national legislation to counter illegal migration with an arithmetic mean of 2.51. Finally. The lowest ranked factor was the weak legal protection programs for victims of illegal migration with an arithmetic mean of 2.36 . 
Egyptian Journal of Social Work (EJSW)

http://ejsw.journals.ekb.eg

Print ISSN: 2356-9204 Online ISSN: 2356-9212

Vol 7, Issue 1, January 2019

(3) Obstacles Related to Governmental and Civil Organizations:

Table (5) obstacles related to governmental and civil organizations as determined by the officials.

\begin{tabular}{|c|c|c|c|c|}
\hline $\mathrm{N}$ & The Phrases & Mean & $\begin{array}{c}\text { Std. } \\
\text { D }\end{array}$ & Rank \\
\hline 1 & $\begin{array}{l}\text { Lack of funds to implement plans to confront illegal } \\
\text { migration }\end{array}$ & 2.47 & 0.66 & 2 \\
\hline 2 & $\begin{array}{l}\text { Weak resources and capabilities to deal with illegal } \\
\text { migration }\end{array}$ & 2.47 & 0.63 & 1 \\
\hline 3 & $\begin{array}{l}\text { Conflicts of some interests between governmental } \\
\text { and non-governmental organizations }\end{array}$ & 2.4 & 0.75 & 4 \\
\hline 4 & $\begin{array}{l}\text { Difficulty in accessing services through partnership } \\
\text { between governmental and non-governmental } \\
\text { organizations }\end{array}$ & 2.4 & 0.69 & 3 \\
\hline 5 & $\begin{array}{l}\text { The administrative bureaucracy of the government } \\
\text { when implementing partnership programs with NGOs } \\
\text { to counter illegal migration }\end{array}$ & 2.33 & 0.77 & 5 \\
\hline & Total & 2.41 & 0.52 & $\begin{array}{l}\text { High } \\
\text { level }\end{array}$ \\
\hline
\end{tabular}

\section{The Table Above Shows That:}

The level of the obstacles related to governmental and civil organizations as determined by the officials is high, with an arithmetic mean of 2.41. Indicators according to the order of the arithmetic mean found that the first ranked factor was weak resources and capabilities to deal with illegal migration with an arithmetic mean of 2.47. Ranked second was the lack of funds to implement plans to confront illegal migration with an arithmetic mean of 2.47. Finally, the administrative bureaucracy of the government when implementing partnership programs with NGOs to counter illegal migration was the least important factor with an arithmetic mean of 2.33. 
Egyptian Journal of Social Work (EJSW)

http://ejsw.journals.ekb.eg

Print ISSN: 2356-9204 Online ISSN: 2356-9212 Vol 7, Issue 1, January 2019

(4) Obstacles Related to Information and Communication Technology:

Table (6) obstacles related to Information and Communication Technology as determined by the officials

\begin{tabular}{|c|c|c|c|c|}
\hline $\mathrm{N}$ & The Phrases & Mean & $\begin{array}{c}\text { Std. } \\
\text { D }\end{array}$ & Rank \\
\hline 1 & $\begin{array}{l}\text { Lack of modern technology to implement } \\
\text { partnership programs between governmental and } \\
\text { non-governmental organizations to deal with illegal } \\
\text { migration }\end{array}$ & 2.47 & 0.66 & 1 \\
\hline $\mathrm{N}$ & The Phrases & Mean & $\begin{array}{c}\text { Std. } \\
\text { D }\end{array}$ & Rank \\
\hline 2 & $\begin{array}{l}\text { Do not use modern electronic means to implement } \\
\text { partnership programs between governmental and } \\
\text { non-governmental organizations to address illegal } \\
\text { migration }\end{array}$ & 2.36 & 0.68 & 3 \\
\hline 3 & $\begin{array}{l}\text { Poor information exchange between governmental } \\
\text { and non-governmental organizations to deal with } \\
\text { illegal migration }\end{array}$ & 2.36 & 0.65 & 2 \\
\hline 4 & $\begin{array}{l}\text { Lack of data and accurate information related to the } \\
\text { problem of illegal migration }\end{array}$ & 2.36 & 0.74 & 4 \\
\hline 5 & $\begin{array}{l}\text { No updated data and information related to the } \\
\text { problem of illegal migration }\end{array}$ & 2.22 & 0.77 & 5 \\
\hline & Total & 2.35 & 0.53 & $\begin{array}{l}\text { High } \\
\text { level }\end{array}$ \\
\hline
\end{tabular}

The Table Above Shows That:

The level of the obstacles related to Information and Communication Technology, as determined by the officials, is high, with an arithmetic mean of 2.35. Indicators according to the order of the arithmetic mean: were as follows: first ranked was the lack of modern technology to implement partnership programs between governmental and non-governmental organizations to deal with illegal migration with an arithmetic mean of 2.47.; second ranked was poor information exchange between governmental and non-governmental organizations to deal with illegal migration with an arithmetic mean of 2.36.; and finally, the lack of updated data and information related to the problem of illegal migration with an arithmetic mean of 2.22 . 
Egyptian Journal of Social Work (EJSW)

http://ejsw.journals.ekb.eg

Print ISSN: 2356-9204 Online ISSN: 2356-9212 Vol 7, Issue 1, January 2019

(5) Obstacles Related to Team Work in Governmental and Civil Organizations:

Table (7) obstacles related to Team Work in governmental and civil organizations as determined by the officials

\begin{tabular}{|c|c|c|c|c|}
\hline $\mathrm{N}$ & The Phrases & Mean & $\begin{array}{c}\text { Std. } \\
\text { D }\end{array}$ & Rank \\
\hline 1 & $\begin{array}{l}\text { Little experience of the working group of } \\
\text { governmental and nongovernmental } \\
\text { organizations in partnership programs }\end{array}$ & 2.2 & 0.76 & 2 \\
\hline 2 & $\begin{array}{l}\text { Lack of coordination among members of the } \\
\text { working group of governmental and non- } \\
\text { governmental organizations in partnership } \\
\text { programs }\end{array}$ & 2.16 & 0.77 & 4 \\
\hline 3 & $\begin{array}{l}\text { Lack of sufficient staff to implement } \\
\text { partnership programs }\end{array}$ & 2.09 & 0.7 & 5 \\
\hline 4 & $\begin{array}{l}\text { The lack of interest of the members of the } \\
\text { working group to develop the skills of their } \\
\text { African work }\end{array}$ & 2.22 & 0.67 & 1 \\
\hline 5 & $\begin{array}{l}\text { Low level of awareness among members of the } \\
\text { working group on the importance of partnership } \\
\text { between governmental and non-governmental } \\
\text { organizations to combat illegal migration }\end{array}$ & 2.18 & 0.65 & 3 \\
\hline & Total & 2.17 & 0.55 & $\begin{array}{c}\begin{array}{c}\text { Medium } \\
\text { level }\end{array} \\
\end{array}$ \\
\hline
\end{tabular}

\section{The Table Above Shows That:}

The level of the obstacles related to team work in governmental and civil organizations as determined by the officials is not particularly strong with an arithmetic mean of 2.17. The indicators according to the order of the arithmetic mean are as follows: ranked first was the lack of interest of the members of the working group to develop the skills of their African work with an arithmetic mean of 2.22; ranked second was little experience of the working group of governmental and non-governmental organizations in partnership programs with an arithmetic mean of 2.2; and finally, the lack of sufficient staff to implement partnership programs with an arithmetic mean of 2.09 .

\section{Second: The Test of Hypotheses:}

(2-1) Test the first study hypothesis: "It is expected that the level of obstacles faced by partnerships between governmental and civil organizations to tackle illegal migration in Egypt is high"

Table (8) the level of obstacles facing partnerships between governmental and civil organization to tackle illegal migration in

Egypt as determined by the officials 
Egyptian Journal of Social Work (EJSW)

http://ejsw.journals.ekb.eg

Print ISSN: 2356-9204 Online ISSN: 2356-9212

Vol 7, Issue 1, January 2019

\begin{tabular}{||c||l||c||c||c||c||}
\hline \hline N & \multicolumn{1}{|c||}{ The Obstacles } & Mean & $\begin{array}{c}\text { Std. } \\
\text { D }\end{array}$ & Level & Rank \\
\hline \hline 1 & $\begin{array}{l}\text { Obstacles Related to Policies that Confront } \\
\text { Illegal Migration. }\end{array}$ & 2.6 & 0.35 & High & 1 \\
\hline \hline 2 & Obstacles Related to Laws and Legislation. & 2.48 & 0.48 & High & 2 \\
\hline \hline 3 & $\begin{array}{l}\text { Obstacles Related to Governmental and } \\
\text { Civil Organizations. }\end{array}$ & 2.41 & 0.52 & High & 3 \\
\hline \hline 4 & $\begin{array}{l}\text { Obstacles Related to Information and } \\
\text { Communication Technology }\end{array}$ & 2.35 & 0.53 & High & 4 \\
\hline \hline 5 & $\begin{array}{l}\text { Obstacles Related to Team Work in } \\
\text { Governmental and Civil Organizations. }\end{array}$ & 2.17 & 0.55 & Medium & 5 \\
\hline \hline \multicolumn{2}{|l|}{ The Obstacles as a whole } & 2.4 & 0.34 & High Level \\
\hline
\end{tabular}

\section{The Table Above Shows That:}

The level of obstacles facing partnerships between governmental and civil tackle illegal migration in Egypt as determined by the officials was as follows:

- Ranked first: Obstacles related to policies confront illegal migration with an arithmetic mean of 2.6

Ranked second: Obstacles Related to laws and legislation with an arithmetic mean of 2.48 .

- Ranked third: Obstacles related to governmental and civil organizations with an arithmetic mean of 2.41.

Ranked fourth: Obstacles related to information and communication technology with an arithmetic mean of 2.35.

Ranked fifth: Obstacles related to team work in governmental and civil organizations with an arithmetic mean of 2.17.

The results indicate that the general mean of the obstacles faced by partnerships between governmental and civil efforts to confront illegal migration in Egypt as determined by officials reached 2.4, which is a strong indicator. This finding supports the first hypothesis of the study, which states that "It is expected that the level of obstacles faced by partnerships between governmental and civil efforts to tackle illegal migration in Egypt is high ".

(2-2)Test the second hypothesis of the study: "There are statistically significant differences between the responses of officials of governmental and civil organizations in terms of identifying the obstacles facing partnerships between governmental and civil organization to tackle illegal migration in Egypt ": 
Egyptian Journal of Social Work (EJSW)

http://ejsw.journals.ekb.eg

Print ISSN: 2356-9204 Online ISSN: 2356-9212

Vol 7, Issue 1, January 2019

Table (9) significant differences between the responses of officials of governmental and civil organizations in terms of identifying the obstacles to facing partnerships between governmental and civil organizations illegal migration in Egypt, using the T-Test $\quad(\mathrm{N}=45)$

\begin{tabular}{|c|c|c|c|c|c|c|c|c|}
\hline $\mathrm{N}$ & The Obstacles & $\begin{array}{c}\text { Research } \\
\text { Community } \\
\end{array}$ & $\mathrm{N}$ & Mean & Std.D & df & $\mathrm{T}$ & Sig \\
\hline \multirow[t]{2}{*}{1} & \multirow{2}{*}{$\begin{array}{l}\text { Obstacles Related to } \\
\text { Policies Ttackling } \\
\text { Illegal Migration }\end{array}$} & Governmental & 15 & 2.52 & 0.34 & \multirow[t]{2}{*}{43} & \multirow[t]{2}{*}{1.148} & \multirow[t]{2}{*}{ - } \\
\hline & & Civil & 30 & 2.65 & 0.35 & & & \\
\hline \multirow[t]{2}{*}{2} & \multirow{2}{*}{$\begin{array}{l}\text { Obstacles Related to } \\
\text { Laws and Legislation }\end{array}$} & Governmental & 15 & 2.44 & 0.45 & \multirow[t]{2}{*}{43} & \multirow[t]{2}{*}{0.437} & \multirow[t]{2}{*}{ - } \\
\hline & & Civil & 30 & 2.51 & 0.49 & & & \\
\hline \multirow[t]{2}{*}{3} & \multirow{2}{*}{$\begin{array}{l}\text { Obstacles Related to } \\
\text { Governmental and } \\
\text { Civil Organizations } \\
\end{array}$} & Governmental & 15 & 2.55 & 0.37 & \multirow[t]{2}{*}{43} & \multirow[t]{2}{*}{1.220} & \multirow[t]{2}{*}{ - } \\
\hline & & Civil & 30 & 2.35 & 0.58 & & & \\
\hline \multirow[t]{2}{*}{4} & \multirow{2}{*}{$\begin{array}{l}\text { Obstacles Related to } \\
\text { Information and } \\
\text { Communication } \\
\text { Technology }\end{array}$} & Governmental & 15 & 2.55 & 0.38 & \multirow[t]{2}{*}{43} & \multirow[t]{2}{*}{1.777} & \multirow[t]{2}{*}{ - } \\
\hline & & Civil & 30 & 2.25 & 0.58 & & & \\
\hline \multirow[t]{2}{*}{5} & \multirow{2}{*}{$\begin{array}{l}\text { Obstacles Related to } \\
\text { Team Work in } \\
\text { Governmental and } \\
\text { Civil Organizations }\end{array}$} & Governmental & 15 & 2.45 & 0.31 & \multirow[t]{2}{*}{43} & \multirow[t]{2}{*}{2.596} & \multirow[t]{2}{*}{ * } \\
\hline & & Civil & 30 & 2.03 & 0.6 & & & \\
\hline \multirow{2}{*}{\multicolumn{2}{|c|}{ The Obstacles as a whole }} & Governmental & 15 & 2.5 & 0.32 & \multirow[t]{2}{*}{43} & \multirow[t]{2}{*}{1.377} & \multirow[t]{2}{*}{ - } \\
\hline & & Civil & 30 & 2.36 & 0.34 & & & \\
\hline
\end{tabular}

** Significant at the $(0.01)$ level * Significant at the $(0.05)$ level

\section{The Table Above Shows That:}

- There are statistically significant differences at a significant level of .05 between the responses of officials of the governmental and civil organizations in terms of identifying the obstacles related to team work in governmental and civil organizations to tackling illegal migration in Egypt in favor of the responses of officials in government organizations.

- There are no statistically significant differences between the responses of officials of governmental and civil organizations in terms of identifying the obstacles related to policies tackling illegal migration, obstacles related to laws and legislation, obstacles related to governmental and civil organizations, obstacles related to information and communication technology, or the obstacles to partnerships between governmental and civil organizations tacking illegal migration in Egypt as a whole.

- These findings support the second hypothesis in the study: "There are statistically significant differences between the responses of officials of governmental and civil organizations in 
terms of identifying the obstacles facing partnerships between governmental and civil organizations tackling illegal migration in Egypt ".

\section{Discussion:}

The results of the study indicate the achievement of the main hypotheses and sub-sections. And it also identified the obstacles of partnership between governmental and civil organizations when facing and tackling illegal migration in Egypt .These are supported by the studies finding of Salah (2011) and Tahar (2012).

The results of the study found that there were many obstacles related to teamwork in government and civil organizations related to the lack of sufficient numbers of these organizations and low levels of training for the team .This is agreed with Sayed (2011) who pointed to the importance of teamwork in the organizations.

The results of the study on the obstacles related to governmental organizations and the eligibility for the same resources and difficulties in achieving the objectives facing illegal migration in Egypt. This is agreed with Ataya (2016) who pointed to the partnership between governmental and civil organizations.

The Limited activated results from the governmental and civil originations that were found in Egypt can be achieved again under the same conditions .

In light of the first study objective identify the obstacles of partnership between government and non-government efforts illegal migration in Egypt.

The study identified these obstacles associated with the policies of illegal immigration with the most important factor being the absence of a special strategy to confront illegal migration and severity of the difference between the partnerships. In addition, the findings of this study identified obstacles that are linked to the laws with the most important issue being the lack of both national legislation to confront illegal migration and the use of information technology.

In light of the second study objective" Identify the differences between governmental and non-governmental organizations regarding the obstacles of partnership to face illegal migration in Egypt".

The study identified the rise of public awareness in the public aspect of the government side, especially on the subject of policies and legislation on illegal migration. 
In light of the third study objective "Attempting to arrive at a proposed future vision from perspective of the way in which the community is organized to increase the partnership between governmental and non-governmental organizations in Egypt". The study identified the importance of developing a national strategy to confront illegal migration, as well as prepare social workers with the skills and expertise to deal with issue of illegal migration.

\section{Study Suggestions;}

1) Creating national strategy to tackle illegal migrations is imperative to be developed.

2) Increase awareness of the importance of partnerships between governmental and non-governmental organizations tackling illegal migrations.

3) Prepare an easily accessible database to exchange information and achieve technological communication between governmental and non-governmental organizations during the process of creating partnerships between organizations.

4) Form an integrated team that combines all governmental and private expertise 


\section{Refernces :}

Abdel Satar, Maha, K. (2014), The role of government agencies in confronting the phenomenon of illegal migration in the Egyptian Society, Master's Degree, Institute of international transport, Arab Academy for Science and Technology.

Abo El-Nasser, Medhat (2007), Community organizations conducted study in private associations from the perspective of empowerment, partnership, transparency, issue, leadership and volunteerism and quality, Isaac publishing and Distribution.

Ataya, Sahar BM. (2016), the role of partnership in support of community service universities: future vision from the perspective of community organizations, Egyptian Association of Social workers.

Business partners for Development.(2000), Natural resources cluster the needs Nite: A new Approach, London, World Bank.

Ebrahim , Mohamed EA. (2008), Illegal immigration and Social Problems, Alexandria, Modern University Office.

Hassan, Amiar MM. (2014), Partnership between governmental organizations and civil society to develop the slums, Ph.D. degree, faculty of social work, Helwan University.

Heder, Heidi M. (1995), Partnership for environmental conservation in Manitoba:Environmental non-government organizations and government agencies, University of Manitoba (Canada), pro Quest publishing.

Human Development Report. (2014), Social contract in Egypt, the role of civil society, Cairo, United Nations development program.

Jenny, Kuhlmann. (2012),Encyclopedia of Global studies, sage publications, Inc., Thousand Oaks.

National Center for Social and Criminal Research.(2016), National coordinating committee for combating and preventing illegal immigrations, National council for Human Rights, illegal migrations for Egyptian Youth, Cairo.

Report of the Egyptian Human Rights organization. (2007), Egyptian Youth migrations, decision to the unknown, Cairo.

Sayad, Rabya AD. (2011), the efforts of private associations in community awareness of the dangers of illegal immigrations, Master's Degree, faculty of social work, Helwan University. 
Saadi,Reem. (2006), Egyptian workers in Pairs, Pilot Ethnography, SRC, American University in Cairo.

Salah, Rabia K. (2005), The social and cultural dimensions of the emigration of the Egyptian countryside to Italy, Ph.D. Degree, faculty of literature, El-Fayyum University.

Sherif, Ali. (2005), Management of government organizations.

Sun, Qiu. (2008), the partnership between government and NGO's in UK. Taking the housing service in Trafford as the case, Huazhong Normal University, Pro Quest Dissertations publishing.

Tahar,Hala K.(2012), Schematic indicators to reduce illegal migration among Egyptian Youth, College of Educations, ElFayyum University, May.

UNESCO. (2003), United Nations Convention on the Rights of Migrants, International Convention on the protection of All Migrant workers and Members of their families, Paris.

Yoshida, Chisato.(2000), Illegal Immigration and Economic welfare, faculty of economic Okayma, University of Japan. 